\title{
Intrahepatic Bile Duct Cancer Pathologic TNM Finding v8
}

National Cancer Institute

\section{Source}

National Cancer Institute. Intrahepatic Bile Duct Cancer Pathologic TNM Finding v8. NCI

Thesaurus. Code C134582.

A pathologic finding about one or more characteristics of intrahepatic bile duct cancer, following the rules of the TNM AJCC v8 classification system. 